\title{
Evaluating salinity distribution in soil irrigated with saline water in arid regions of northwest China
}

\author{
Weiping Chen ${ }^{\mathrm{a}}$, Zhenan $\mathrm{Hou}^{\mathrm{b}, *}$, Laosheng $\mathrm{Wu}^{\mathrm{c}}$, Yongchao Liang ${ }^{\mathrm{b}}$, Changzhou Wei ${ }^{\mathrm{b}}$ \\ a State Key Lab of Urban and Regional Ecology, Research Center for Eco-Environmental Sciences, Chinese Academy of Sciences, Beijing 100085, China \\ ${ }^{b}$ Department of Resources and Environmental Sciences, Shihezi University, No. 4, North Road, Shihezi, Xinjiang 832003, China \\ ' Department of Environmental Sciences, University of California, Riverside, CA 92521, USA
}

\section{A R T I C L E I N F O}

\section{Article history:}

Available online 25 June 2010

\section{Keywords:}

Irrigation management

Soil salinity

Model

\begin{abstract}
A B S T R A C T
In arid and semi-arid regions, salinity is a serious and chronic problem for agriculture. A 3-year field experiment in the arid environment of Xinjiang, northwest China, was conducted to study the salinity change in soil resulting from deficit irrigation of cotton with non-saline, moderate saline and high saline water. The salinity profile distribution was also evaluated by an integrated water, salinity, and nitrogen model, ENVIRO-GRO. The simulated and observed salinity distributions matched well. Results indicated that after 3 years of cotton production, the average salinity in the $1.0-\mathrm{m}$ soil profile was $336 \%$ and $547 \%$ of the original soil profile, respectively, for moderate saline and high saline water irrigation. If the practices continued, the average soil salinity $\left(\mathrm{EC}_{\mathrm{e}}\right)$ in the 1.0 -m soil profile would approach a steady level of $1.7,10.8$, and $14.7 \mathrm{dS} \mathrm{m}^{-1}$, respectively, for the treatments receiving irrigation waters of $0.33,3.62$, and $6.71 \mathrm{dS} \mathrm{m}^{-1}$. It was concluded that deficit irrigation of saline water in this region was not sustainable. Model simulation showed that a big flood irrigation after harvest can significantly reduce the salt accumulation in the soil profile, and that this practice was much more efficient for salinity control than applying the same extra amount of water during the growing season.
\end{abstract}

(C) 2010 Elsevier B.V. All rights reserved.

\section{Introduction}

In irrigated cropland of semi-arid and arid regions, salinity is a serious and chronic problem (van Schilfgaarde, 1994). Salinity impacts about one-third $\left(1.23 \times 10^{6} \mathrm{ha}\right)$ of the total irrigated cropland in Xinjiang, northwest China (Hou et al., 2007). It was estimated that the salt accumulation in the irrigated croplands of Xinjiang was increased by 40\% from 1983 to 2005 (Wang et al., 2008). In Xinjiang, irrigation water sources are often brackish since high-quality water for agricultural purposes is becoming scare due to rising demands from urban areas. The salinity level for most of the shallow groundwater sources in this region is greater than $2 \mathrm{dS} \mathrm{m}^{-1}$. Sustainable crop productivity in these regions is severely challenged by the diminishing available water and rising salinity.

The future of irrigated agriculture will need to include the use of waters containing higher levels of soluble salts, particularly in arid and semi-arid regions (Oster and Wichelns, 2003; Malash et al., 2008). The key to saline water irrigation is maintaining the salinity level of the root zone through leaching, which can be achieved through flushing excessive soluble salts out of the root zone during the growing season or additional leaching at the end of the

\footnotetext{
* Corresponding author. Tel.: +86993 2058076; fax: +869932057990.

E-mail address: hzatyl@163.com (Z.Hou).
}

season (Corwin et al., 2007). This requires the understanding of the interactions between irrigation, soil salinity, and crop performance.

The interactions between salinity and plant water uptake are complex and affected by many factors. Evaluating the interaction of these factors through field research is difficult and expensive because numerous uncontrolled factors may affect crop performance in addition to the controlled variables. In addition, the magnitude of salt accumulation in a single growth season is often small and may not be readily detectable by the routine soil sampling in the field. Simulation models that integrate the effects of management on crop growth and leaching of chemicals below the root zone, on the other hand, provide a means of supplementing information gained from field experiment (Singh and Singh, 1996). There are numbers of models dealing with plant growth, water flow, and agricultural chemical movement, including GLEAMS (Leonard et al., 1987), LEACHM (Hutson and Wagenet, 1992), UNSATCHEM (Simunek et al., 1996), RZWQM (Hanson et al., 1998), SWAGMAN (Khan et al., 2003), and SALTMED (Ragab et al., 2005). Combining with a 3-year field experiment, Forkutsa et al. (2009a,b) applied the soil-water model Hydrus-1D to understand the effects of water management strategies on soil salinity under cotton irrigated with shallow groundwater. Using an integrated water, salinity, and nitrogen model, ENVIRO-GRO, Feng et al. (2003a,b) evaluated effects of irrigation management under saline conditions on plant growth and salt distribution. 
Table 1

Chemical characteristics of the three irrigation water.

\begin{tabular}{|c|c|c|c|c|c|c|c|}
\hline \multirow[t]{2}{*}{ Water salinity $\left(\mathrm{dS} \mathrm{m}^{-1}\right)$} & \multirow[t]{2}{*}{$\mathrm{pH}$} & \multirow[t]{2}{*}{$\operatorname{SAR}\left(\mathrm{mmol} \mathrm{L}^{-1}\right)^{1 / 2}$} & \multicolumn{5}{|c|}{ Ion concentration $\left(\mathrm{mmol} \mathrm{L}^{-1}\right)$} \\
\hline & & & $\mathrm{K}^{+}$ & $\mathrm{Na}^{+}$ & $\mathrm{Ca}^{2+}$ & $\mathrm{Mg}^{2+}$ & $\mathrm{Cl}^{-}$ \\
\hline 0.3 & 7.54 & - & 0.03 & - & 1.22 & 0.59 & 2.45 \\
\hline 3.6 & 7.20 & 7.31 & 0.05 & 16.4 & 9.50 & 0.61 & 35.5 \\
\hline 6.7 & 7.13 & 10.4 & 0.10 & 31.8 & 18.12 & 0.60 & 68.1 \\
\hline
\end{tabular}

In Xinjiang, saline water is increasingly used by drip irrigation in cotton (Gossipium hirsutum L.), a highly salinity tolerant plant. Drip irrigation is thought to be the most efficient irrigation method, which can distribute water more uniformly, control the amount of water application more precisely, and more effectively reduce evaporation and deep percolation (Mohammad, 2004). The irrigation practice (deficit irrigation with poor quality water) however is questionable with regard to its long-term sustainability for the agricultural development in Xinjiang where rainfall is insufficient to provide adequate leaching. In the short term, considerable salt may be stored in the root zone without causing significant yield loss. Prolonged deficit irrigation with poor quality water eventually, however, may cause "secondary salinization", progressively decrease yield and compromise the soil resources (Beltran, 1999; Dudely et al., 2008)

The objective of this research is to evaluate the effect of deficit irrigation in a cotton field applied with different levels of water salinity under arid climate conditions of Xinjiang on the change of soil salinity based on a 3-year field experiment and simulation outcomes from the revised ENVIRO-GRO model.

\section{Materials and methods}

\subsection{Field experiment}

The field experiments were conducted at an agricultural experiment station of Shihezi University, located in Shihezi, Xinjiang in the northwestern China $\left(44^{\circ} 18^{\prime} \mathrm{N}, 86^{\circ} 02^{\prime} \mathrm{E}\right)$. The region is classified as a warm-temperate arid zone with continental climate. The average annual precipitation is about $170 \mathrm{~mm}, 60 \%$ or more of which occurs between April and August. The annual mean temperature is $6.9^{\circ} \mathrm{C}$ and annual total sunshine is $2770 \mathrm{~h}$. The long-term mean maximum and minimum air temperature is $26.1^{\circ} \mathrm{C}$ in July and $-18{ }^{\circ} \mathrm{C}$ in January, respectively. The relative humidity during summer months varies from $30 \%$ to $50 \%$. Annual potential evaporation is about $1660 \mathrm{~mm}$. The elevation ranges from 300 to $400 \mathrm{~m}$. The groundwater (generally has a EC of $3-5 \mathrm{dS} \mathrm{m}^{-1}$ ) table is about $6 \mathrm{~m}$ from the surface. The study site has a flat topography. The gray desert soils in the study area are of alluvial origin. The soil bulk density varies from 1.27 to $1.45 \mathrm{Mg} \mathrm{m}^{-3}$ in the $1-\mathrm{m}$ soil profile, with a $\mathrm{pH}$ range of 7.50-7.88. The average electrical conductivity of the soil saturation extract $\left(\mathrm{EC}_{\mathrm{e}}\right)$ in the soil profile varies from 1.15 to $1.90 \mathrm{dS} \mathrm{m}^{-1}$.

Cotton (G. hirsutum L., cv. Xinluzao 13) was grown from 2004 to 2006. The sowing took place in late-April and the har- vest took place around mid-September each year. To reduce the variability in soil salinity and volumetric water content at the beginning of the study, $120 \mathrm{~mm}$ of fresh water $\left(\mathrm{EC}=0.3 \mathrm{dS} \mathrm{m}^{-1}\right)$ was applied by flood irrigation in 2004. There were three irrigation water treatments, i.e. non-saline water with EC of $0.3 \mathrm{dS} \mathrm{m}^{-1}$, moderate saline water with EC of $3.6 \mathrm{dS} \mathrm{m}^{-1}$, and high saline water with $\mathrm{EC}$ of $6.7 \mathrm{dS} \mathrm{m}^{-1}$. The saline water was obtained by adding $\mathrm{NaCl}$ and $\mathrm{CaCl}_{2}$ to the non-saline water. The elemental composition of the irrigation waters is shown in Table 1.

The spatial distribution of the experimental plots followed a randomized block design. For each irrigation treatment, there were six replicates (plots). In each plot, there were two $1.2 \mathrm{~m} \times 25 \mathrm{~m}$ beds, with a 0.6 -m separation distance. Each bed had four plant rows with a $0.3-\mathrm{m}$ separation distance and was covered with plastic film. Two irrigation dripper lines were installed under the plastic film. The cotton plants were sown at $0.1-\mathrm{m}$ intervals in the row to yield a population of 222,000 plants ha ${ }^{-1}$.

The irrigation schemes for the three growing seasons are summarized in Table 2. The irrigation schedules were based on the local recommendations for the non-saline soils of the area. During the 3 years of experiment, the applied irrigation water was 375,345 , and $353 \mathrm{~mm}$ in 2004, 2005, and 2006, respectively. For all treatments, equal volumes of water were irrigated each year. Plots were drip-irrigated with $30 \mathrm{~mm}$ fresh water to improve germination and seedling establishment after sowing in 2005 and 2006. Drip irrigation was commenced towards the early June and continued up to August during the cotton growing season. The irrigation interval was 7-15 days according to field practices used by local farmers. Water meters were used to record the amount of water each plot received.

To meet the cotton nutrient requirements, $225 \mathrm{~kg} \mathrm{Nha}^{-1}$, $105 \mathrm{~kg} \mathrm{P}_{2} \mathrm{O}_{5} \mathrm{ha}^{-1}$, and $60 \mathrm{~kg} \mathrm{~K}_{2} \mathrm{O} \mathrm{ha}^{-1}$ were applied each year. Prior to sowing, triple superphosphate and potassium sulfate were applied uniformly as base fertilizers and were mixed well by plowing. Urea was applied in five equal splits through the drip irrigation system during the cotton growing period. The fertilizer solution was stored in a 100-L plastic container and was pumped into the irrigation system.

Salinity distribution along the soil profile was monitored at end of each crop season and weekly during the 2006 growing season. Soil samples were taken at 0.15 and $0.30 \mathrm{~m}$ from the emitter (both sides) at depths of $0-0.2,0.2-0.4,0.4-0.6,0.6-0.8$ and $0.8-1.0 \mathrm{~m}$. Soil salinity was determined by measuring the electrical conductivity (EC) of the saturation extracts with a DDS-308A conductivity

Table 2

Amounts of rainfall and irrigation $(\mathrm{mm})$ of the experimental site for the three growing seasons.

\begin{tabular}{|c|c|c|c|c|c|c|c|c|c|}
\hline \multirow[t]{2}{*}{ Year } & \multirow[t]{2}{*}{ Potential $\mathrm{ET}_{\mathrm{c}}$} & \multicolumn{2}{|c|}{ Amount of rainfall } & \multicolumn{6}{|c|}{ Amount of irrigation water } \\
\hline & & Growth season & Total & April & May & June & July & August & Total \\
\hline 2004 & 647 & 146 & 190 & $120^{a}$ & 0 & 36 & $45+45+45$ & $45+36^{a}$ & 372 \\
\hline 2005 & 618 & 110 & 149 & 0 & $30^{\mathrm{a}}$ & $45+45$ & $45+45+45$ & $45+45^{a}$ & 345 \\
\hline 2006 & 655 & 100 & 149 & 0 & $30^{\mathrm{a}}$ & $45+45$ & $45+45+38$ & $45+30+30$ & 353 \\
\hline
\end{tabular}

a Amount of non-saline water applied to the saline water irrigation treatments. 
meter (Shanghai Precision \& Scientific Instrument Inc., Shanghai, China).

\subsection{Model description}

The ENVIRO-GRO model was originally developed by Pang and Letey (1998). The model simulates movement of water, salts and nitrogen in the root zone and crop growth in response to water, salinity and nitrogen stresses. The model had a better scheme to address the interactions between salinity, crop water uptake and plant growth. Under stressed conditions resulting from inadequate soil-water content or excessive salinity ( $\mathrm{N}$ stress was not considered in this research), plant growth is reduced, which in turn results in reduced ET. A relative plant growth factor $\left(R_{\mathrm{f}}\right)$ which equals the relative water uptake (plant growth and water uptake relative to what would occur under non-stressed conditions) is adopted to adjust the water uptake under stress conditions. When water stress exists in any portion of the root system, water uptake occurs from portions without water stress (Pang and Letey, 1998; Feng et al., 2003a).

In this research, the revised ENVIRO-GRO model was used, which has more accurate numerical solution and with user-friendly input and output data management interfaces. In the revised model, the water flow is modeled by the one-dimension Richard's equation:

$\frac{\partial \theta}{\partial t}=\frac{\partial}{\partial z}\left[K(\theta) \frac{\partial H}{\partial z}\right]+A(z, t)$

where $\theta$ is the volumetric water content of the soil $\left(\mathrm{cm}^{3}\right.$ water $\mathrm{cm}^{-3}$ soil); $H$ is soil hydraulic head $(\mathrm{cm}), A(z, t)$ represents the plant water uptake term $\left(\mathrm{cm}^{3} \mathrm{~cm}^{-3} \mathrm{~h}^{-1}\right) ; K(\theta)$ represents the unsaturated hydraulic conductivity as a function of $\theta\left(\mathrm{cm} \mathrm{h}^{-1}\right)$. The van Genuchten (1980) equation is used to describe the soil-water characteristic relationship between $h$ and $K(h)$, with $h$ being the matric head. The upper boundary and lower boundary conditions are set as atmospheric boundary condition and free drainage, respectively.

Plant root water uptake (term A in Eq. (1)) is simulated by the empirical equation developed by van Genuchten (1987):

$A(z, t)=T_{p}(t) \Gamma(z, t) \sigma(h, \pi)$

where $T_{p}(t)$ is potential transpiration rate $\left(\mathrm{cm} \mathrm{h}^{-1}\right) ; \Gamma(z, t)$ is a plant root distribution function; and $\sigma(h, \pi)$ is a crop matric potential salinity stress function. Root growth is simulated by the classical Verhulst-Pearl logistic function. The additive stress function suggested by van Genuchten (1987) is selected, which is given by

$\sigma(h, \pi)=\frac{1}{1+\left[\left((\alpha h+\pi) / \pi_{50}\right)\right]^{3}}$

where $h$ is soil matric potential, $\pi$ is soil osmotic potential, $a=\pi_{50} / h_{50}$ with $\pi_{50}$ and $h_{50}$ being the osmotic head and the matric potential at which transpiration is reduced by $50 \%$, respectively.

Salinity in the water is considered to be conservative, namely, no dissolution, precipitation, or plant uptake of salts. Salt movement is governed by the convection-dispersion equation (CDE):

$\frac{\partial\left(\theta C_{s}\right)}{\partial t}=\frac{\partial}{\partial z}\left[D_{s}(\theta, v) \frac{\partial C_{s}}{\partial z}-v C_{s}\right]$

where $C_{s}$ is the salt concentration, $v$ is the pore water velocity as $v=$ $q / \theta, q$ is water flux, and $D$ is a combined diffusion and hydrodynamic dispersion coefficient.

\subsection{Model parameters}

The top 1.0-m soil profile was divided into 5 equal layers. To set the free drainage condition at the $2-\mathrm{m}$ depth, the bottom 1 -
Table 3

Soil hydraulic properties of the five soil layers used in the model simulation.

\begin{tabular}{llllll}
\hline \multicolumn{5}{l}{ Soil layer $(\mathrm{m})$} \\
\cline { 2 - 6 } & $0-0.2$ & $0.2-0.4$ & $0.4-0.6$ & $0.6-0.8$ & $0.8-1.0$ \\
\hline$\theta_{r}\left(\mathrm{~cm}^{3} \mathrm{~cm}^{-3}\right)$ & 0.061 & 0.055 & 0.051 & 0.064 & 0.075 \\
$\theta_{s}\left(\mathrm{~cm}^{3} \mathrm{~cm}^{-3}\right)$ & 0.43 & 0.42 & 0.43 & 0.41 & 0.41 \\
$K_{s}\left(\mathrm{~cm} \mathrm{~h}^{-1}\right)$ & 1.24 & 2.75 & 2.69 & 0.70 & 0.53 \\
$\alpha\left(\mathrm{cm}^{-1}\right)$ & 0.010 & 0.020 & 0.023 & 0.013 & 0.009 \\
$n$ & 1.53 & 1.53 & 1.46 & 1.47 & 1.50 \\
\hline
\end{tabular}

$\theta_{r}$ is the residual water content; $\theta_{s}$ is the saturated water content; $K_{s}$ is the saturated hydraulic; $\alpha$ is the inverse of the air-entry value or bubbling pressure; $n$ is a pore-size distribution index.

$\mathrm{m}$ profile used the same soil properties of the 5th layer in the top $1-\mathrm{m}$ profile. The numerical simulation was conducted using an incremental depth interval, $\mathrm{dz}$, of $0.01 \mathrm{~m}$. The molecular diffusion coefficient for salt was set to $0.02 \mathrm{~cm}^{2} \mathrm{~h}^{-1}$, based on Hollins et al. (2000). The longitudinal dispersivity was set to $0.01 \mathrm{~m}$ based on Gelhar et al. (1985) and Lyman et al. (1992).

The initial matric potential was set to $-100 \mathrm{~cm}$ in the top $1.0 \mathrm{~m}$ and $-500 \mathrm{~cm}$ in the bottom $1.0 \mathrm{~m}$ soil profile. The initial salt distribution $\left(E_{\mathrm{e}}\right.$ ) was $2.25,1.84,1.79,2.47$ and $3.30 \mathrm{dS} \mathrm{m}^{-1}$, respectively, for the five soil layers downwards. The five parameters defining the soil-water retentivity are summarized in Table 3 . These parameters were obtained from the agricultural experiment station.

Climatic data were obtained from local weather station and the reference evapotranspiration $\left(\mathrm{ET}_{0}\right)$ was calculated based on the dual approach version of the FAO-56 Penman-Monteith equation (Allen et al., 1998). The crop evapotranspiration $\left(\mathrm{ET}_{\mathrm{c}}\right.$ ) was estimated based on the $\mathrm{ET}_{0}$ and the crop coefficients from field observation (Allen et al., 1998). The potential $\mathrm{ET}_{\mathrm{c}}$ is 647,618 and $655 \mathrm{~mm}$, respectively for the crop year of 2004, 2005 and 2006. Water inputs during the crop season including irrigation and rainfall are 562, 494 and $492 \mathrm{~mm}$, respectively for the three consecutive years (see Table 2 ).

The plant growth and root development parameters were based on field observations. The plant reached the full development stage on the 80th day was harvested on the 145 th day. A root distribution of $40 \%, 30 \%, 20 \%$ and $10 \%$ root in the 1 st, 2 nd, 3rd and 4 th quarter of the $1.0-\mathrm{m}$ root zone was assumed. The salinity stress threshold $\left(E C_{e}\right)$ was set as $7.7 \mathrm{dS} \mathrm{m}^{-1}$, above which it would result in reduced growth. The $\mathrm{EC}_{\mathrm{e}}$ at which growth and transpiration was reduced by $50 \%$ was set as $17 \mathrm{dS} \mathrm{m}^{-1}$. These two values were based on Maas and Grattan (1999). The water stress threshold was set as $-75 \mathrm{kPa}$ (water content of $0.17 \mathrm{~cm}^{3} / \mathrm{cm}^{3}$ ) and the matric potential at which transpiration was reduced by $50 \%$ was set to $-150 \mathrm{kPa}$ (water content of $0.14 \mathrm{~cm}^{3} / \mathrm{cm}^{3}$ ), based on the research results from Plaut et al. (1996) for cotton irrigated with subsurface drip.

\subsection{Statistical analysis}

The agreement between the predicted and observed data was evaluated by Nash-Sutcliffe modeling efficiency (Nash and Sutcliffe, 1970), root mean square error and index of agreement (Willmott, 1981). The equation for calculating the Nash-Sutcliffe modeling efficiency (EF) is given as

$\mathrm{EF}=1-\frac{\sum_{i=1}^{n}\left(O_{i}-P_{i}\right)^{2}}{\sum_{i=1}^{n}\left(O_{i}-O\right)^{2}}$

The equation for calculating the mean square error (RMSE) is given as

$\mathrm{RMSE}=\sqrt{\sum_{i=1}^{n} \frac{\left(P_{i}-O_{i}\right)^{2}}{n}}$ 
Table 4

Irrigation schemes of the four simulation scenarios.

\begin{tabular}{llccccc}
\hline Scenario & \multicolumn{6}{l}{ Amount of irrigation water } \\
\cline { 2 - 7 } & May & June & July & August & Sep. & Total \\
\hline Default & $30^{\mathrm{a}}$ & $45+45$ & $45+45+38$ & $45+30+30$ & & 353 \\
Scenario \#1 & $30^{\mathrm{a}}$ & $62+62$ & $62+62+53$ & $62+40+40$ & & 473 \\
Scenario \#2 & $30^{\mathrm{a}}$ & $70+70$ & $70+70+58$ & $70+46+46$ & & 473 \\
Scenario \#3 & $30^{\mathrm{a}}$ & $45+45$ & $45+45+38$ & $45+30+30$ & $120^{\mathrm{b}}$ & 473 \\
Scenario \#4 & $30^{\mathrm{a}}$ & $45+45$ & $45+45+38$ & $45+30+30$ & $120^{\mathrm{c}}$ & 473 \\
\hline
\end{tabular}

a Fresh water irrigation.

b Flooding fresh water irrigation.

c Flooding saline water irrigation $\left(\mathrm{EC}_{\mathrm{W}}=3.6 \mathrm{dS} \mathrm{m}^{-1}\right)$.

And the equation for calculating the index of agreement (IA) is given as

$\mathrm{IA}=1-\frac{\sum_{i=1}^{n}\left(O_{i}-P_{i}\right)^{2}}{\sum_{i=1}^{n}\left(\left|P_{i}-O\right|+\left|O_{i}-O\right|\right)^{2}}$

where $P_{i}$ is the predicted value corresponding to the observed value $O_{i}$, and $O$ is the observed mean, $P$ is the predicted mean, $O_{i}^{\prime}=O_{i}-O$ and $P_{i}^{\prime}=P_{i}-P$.

In addition, ANOVA analysis was conducted to test the variance among the data obtained from the field by using the SAS for Windows (version 9.0, SAS Institute Inc.) software package.

\subsection{Simulation scenarios}

The outcomes of computer models are useful to answer "what if" types of questions. Starting with a reference scenario, the worst or best possible cases may be illustrated. To demonstrate the efficiency of the model developed in this manuscript, we designed four additional simulation scenarios including increasing irrigation water in the growing season or flooding irrigation after crop harvest to study the effect of different irrigation managements on salt distribution in the soil profile (Table 4). The default (reference) simulation was based on the moderate saline irrigation treatment in this study. For scenarios 1 and 2, the amount of irrigation during the crop season was increased from 353 to $473 \mathrm{~mm}$ and to $530 \mathrm{~mm}$, respectively. For scenarios 3 and 4 , a $120-\mathrm{mm}$ flooding irrigation was applied after crop harvesting. For scenario 3 , fresh water $\left(E C_{W}=0.3 \mathrm{dS} \mathrm{m}^{-1}\right)$ was used for flooding. For scenario 4 , saline water $\left(\mathrm{EC}_{\mathrm{W}}=3.6 \mathrm{dS} \mathrm{m}^{-1}\right)$ was used for flooding. The above described scenarios were conducted by varying the mentioned parameters while holding the values of the other parameters at the default levels.

\section{Results and discussion}

\subsection{Temporal and profile distribution of salts: field measurements vs. model predictions}

The field measurement showed that the horizontal salinity distribution varied with respect to the distance from the emitter. The soil salinity at $0.3-\mathrm{m}$ horizontal distance from the emitter was much higher than that at $0.15-\mathrm{m}$ distance (Fig. 1). After 3 years, the average soil salinity in the 1.0 -m soil profile increased by $336 \%$ and $547 \%$, under the moderate and high saline water treatments, respectively. As expected, the proportional increase in average soil salinity of the two saline water treatments is equal to the proportional increase in irrigation water salinity.

After setting the model parameters according to the above description, the model was run for 3 years of data. The predicted salinity value for the control was lower than the field measured salinity level. For the saline water treatments, the predicted salinity values were within the range of the field measured values at
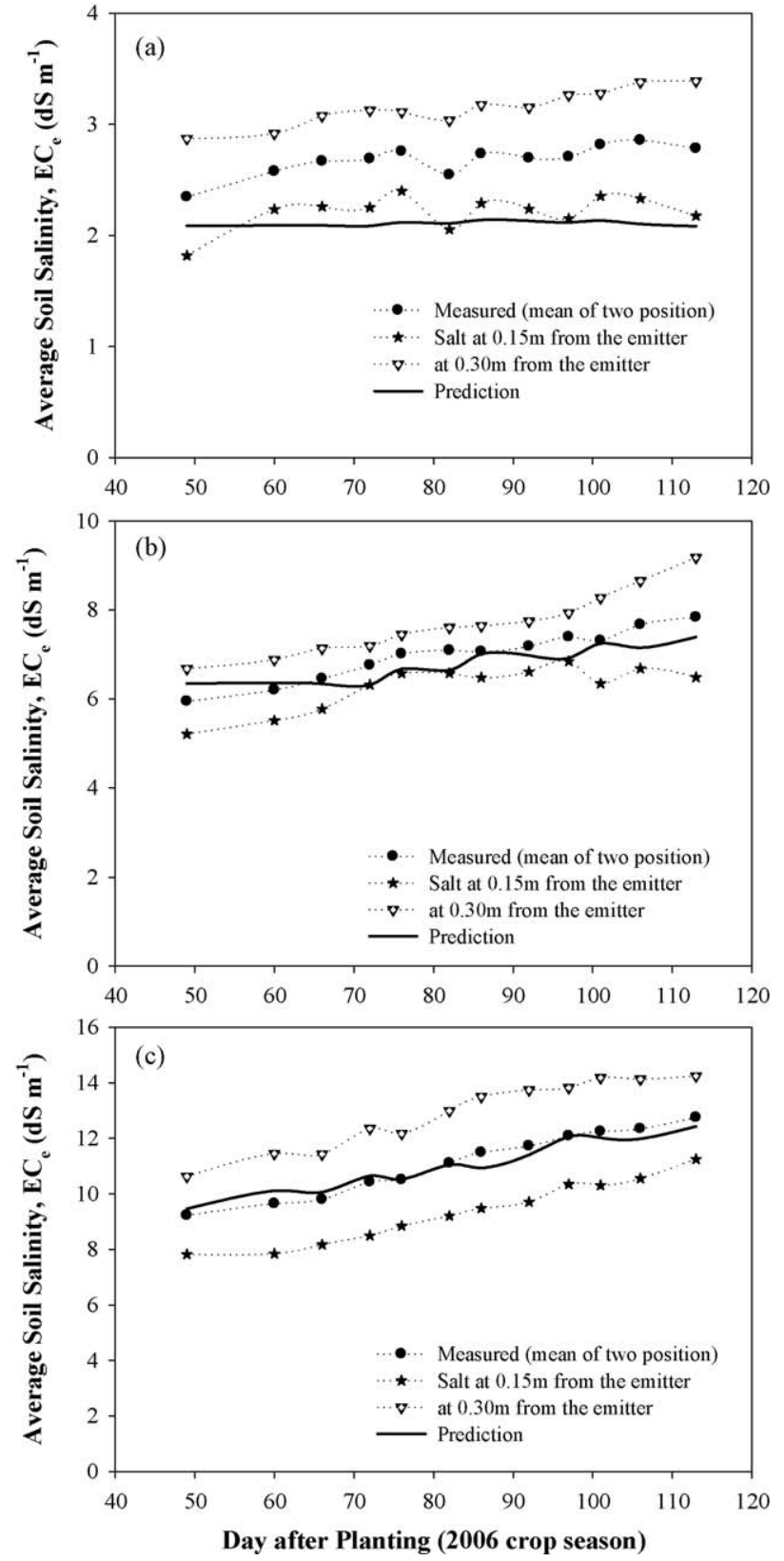

Fig. 1. Measured (dotted line) and predicted (solid line) average soil salinity $\left(E C_{e}\right)$ in the 1.0-m soil profile irrigated with (a) non-saline water, (b) moderate saline water, and (c) high saline water.

the 0.15 and $0.30-\mathrm{m}$ distance from the emitter and were close to their average. The simulated and measured salt distributions at the end of 1st, 2nd and 3rd crop season are presented in Fig. 2. For the non-saline water irrigation treatment, the field measurement showed that the average $\mathrm{EC}_{\mathrm{e}}$ in the $1.0-\mathrm{m}$ soil profile at the end of 1 st crop season decreased from 2.28 to $2.09 \mathrm{dS} \mathrm{m}^{-1}$, which may be attributed to the $120-\mathrm{mm}$ flood irrigation before the start of the first growing season. The salinity in the top $0.2-\mathrm{m}$ soil layer was quite low, accounting only for about $6 \%$ of the total salts in the 1.0 $\mathrm{m}$ soil profile. The salts were primarily accumulated in the middle (0.4-0.6 m) soil layer during the first crop season, which accounted for about 33\% of the total. Salinity started to build up in the soil profile during the 2 nd and $3 r d$ crop season. The average $\mathrm{EC}_{\mathrm{e}}$ in the $1.0-\mathrm{m}$ soil profile increased to 2.33 and $3.32 \mathrm{dS} \mathrm{m}^{-1}$, respectively, in the 2nd and 3rd year. In the mean time, the salts moved downwards during the crop season. At the end of 2 nd crop season, the 

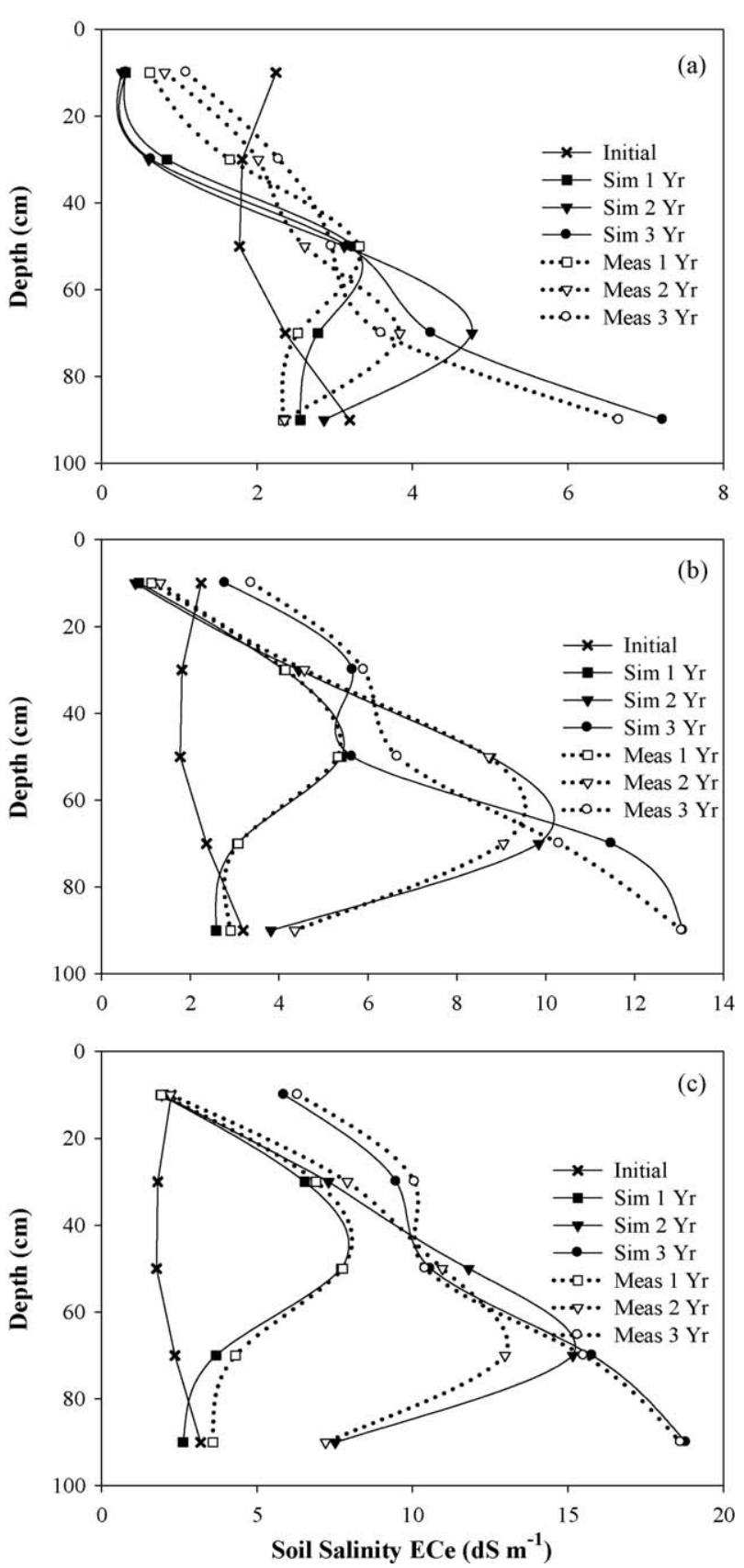

Fig. 2. Measured (dotted line) and predicted (solid line) salt distribution at end of the 1st, 2nd, 3rd crop season under (a) non-saline water, (b) moderate saline water, and (c) high saline water irrigation.

maximum salinity was at the $0.6-0.8 \mathrm{~m}$ soil layer, which accounts for $33 \%$ of the total applied salt. The peak was moved to the bottom soil layer $(0.8-1.0 \mathrm{~m})$ at the end of the 3rd crop season.

Under the moderate saline water irrigation, salts accumulated gradually in the soil profile from an average $\mathrm{EC}_{\mathrm{e}}$ of $2.28 \mathrm{dS} \mathrm{m}^{-1}$ at the beginning to $3.32 \mathrm{dS} \mathrm{m}^{-1}$ at the end of $1 \mathrm{st}$ crop season, to $5.61 \mathrm{dS} \mathrm{m}^{-1}$ at the end of $2 \mathrm{nd}$ crop season, and to $7.86 \mathrm{dS} \mathrm{m}^{-1}$ at the end of the 3rd crop season. For the high saline water irrigation, the average $\mathrm{EC}_{\mathrm{e}}$ of the soil profile increased to $4.90,8.26$, and $12.19 \mathrm{dS} \mathrm{m}^{-1}$, respectively, at the end of $1 \mathrm{st}, 2$ nd and 3rd crop season. The salt distributions followed similar trends to those under the non-saline water irrigation. In general, the salt in the top 0.2$\mathrm{m}$ soil horizon was low and the salt accumulation peak moved downwards with time. Compared to the field measurement, the model simulation underestimated the salinity level in the upper
Table 5

Model performance statistics under the three irrigation water treatments. The observed and correspondingly predicted temporal $(n=12)$ and profile salt distribution data $(n=15)$ were fitted to Eqs. (5)-(7) to obtain the three model efficiency parameters EF, RMSE and IA.

\begin{tabular}{|c|c|c|c|c|c|c|}
\hline \multirow[t]{2}{*}{ Water treatment } & \multicolumn{2}{|l|}{$\mathrm{EF}$} & \multicolumn{2}{|l|}{ RMSE } & \multicolumn{2}{|l|}{ IA } \\
\hline & Temporal & Profile & Temporal & Profile & Temporal & Profile \\
\hline Non-saline & 0.393 & 0.718 & 0.102 & 0.758 & 0.656 & 0.948 \\
\hline Moderate saline & 0.899 & 0.974 & 0.155 & 0.534 & 0.976 & 0.994 \\
\hline High saline & 0.929 & 0.974 & 0.269 & 0.736 & 0.978 & 0.994 \\
\hline
\end{tabular}

part of the soil profile to some extent, which may be attributed to the water uptake pattern towards the end of crop season resulting from large amount of water application and a deep root zone. Additionally, the evaporation rate is set to zero in the model simulation. While the soil is covered with plastic film, there is still certain amount of water lost through evaporation in the field thus certain amount of salts carried by evaporation to soil surface. As a result, the model simulation would underestimate the soil salinity of the surface layer.

The water and salt transport is one-dimensional in the model. But, the actual transport in the field is three-dimensional. During the irrigation, salt around the emitters would move to a further distance and to deeper soil layers. Between irrigation events, the salt might move to the root surface due to water uptake. As a result, the field salt distribution in the soil profile (as shown in Fig. 1) may not be adequately represented by a one-dimensional (1D) model. Nevertheless, the predicted profile distribution follows a similar pattern with the measured profile distribution (Fig. 2). The profile distribution pattern also agrees with the typical salinity profiles of irrigated soil, namely, the soil salinity increase with depth depending on the leaching fraction (Ayers and Westcot, 1985). Additionally, the temporal changes of average soil salinity under 3 years of irrigation were well predicted. All these facts suggest that using the ENVIRO-GRO model to evaluate the management practice on the long-term changes of soil salinity and effects on crop production is justified.

The model performance can be further validated through plant yield. The underlying assumption made in ENVIRO-GRO is that the crop ET is linearly related to total crop mass, or forage yields. Consequently, relative crop water uptake calculated by ENVIRO-GRO can be assumed to equal relative crop mass. However, total crop mass was not measured. Therefore, it is not possible to assess how well the relative yields predicted by the model compare to what occurred during the experiment. The model validation based on crop yield can be achieved in the future research.

\subsection{Model efficiency}

The statistical evaluation results for model performance in terms of Nash-Sutcliffe modeling efficiency (EF), root mean square error (RMSE), and index of agreement (IA) are summarized in Table 5 . The results were for both the temporal $(n=12$, Fig. 1$)$ and profile distribution ( $n=15$, Fig. 2 ) of salts under three different water treatment. The RMSE values were small in all cases, indicating that the predictions were close to the observed data. Under the two saline water treatments, both the EF and IA values were close to 1 , suggesting that the observed and model-simulated means and variances agreed well under the saline water irrigation. Under the non-saline water irrigation treatment, the EF and IA value were 0.393 and 0.656 , respectively, for the temporal distribution of slats during the 3rd growing season. The mean was better predicted than the variation. The model prediction was not perfect but acceptable given the relative small changes of salinity under non-saline water irrigation treatment. Compared with the tempo- 
ral distribution, the profile distribution was better predicted under the non-saline water irrigation treatment. The EF and IA value were 0.718 and 0.948 , respectively.

\subsection{Salt distribution at equilibrium condition}

If the cultivation practices continued, salinity levels in the profile would increase. As the soil salinity increased, the crop water uptake would decrease due to increased salt stress. Consequentially, the leaching would increase under the same amount of water inputs. The amount of salt applied would finally equal to the amount of salt removed by leaching, or a equilibrium condition in terms of salinity levels would be reached. The 10-year field study by Bajwa et al.(1986) showed that soil salinity increased rapidly in the profile during the initial years but after 5 years the average soluble salt concentration in 0-90 cm soil profile did not appreciably vary under the sustained irrigation of saline water with EC of $3.2 \mathrm{dS} \mathrm{m}^{-1}$.

Model simulations were conducted by repeating the simulation conditions of the 3rd crop season to project the number of years when the salinity distributions reach these equilibrium conditions (Fig. 3). For irrigation with non-saline water, the equilibrium conditions were projected to occur after 15 years as compared to less than 10 years for saline water irrigation. Under the equilibrium conditions, the average $\mathrm{EC}_{\mathrm{e}}$ in the 1.0 -m profile would be $1.7,10.8$ and $14.7 \mathrm{dS} \mathrm{m}^{-1}$, respectively, for the non-saline, moderate saline and high saline water treatments. Since there is a greater reduction in growth under higher water salinity irrigation, more salts are leached out the soil profile and the increase in soil salinity is not proportional to the irrigation water salinity.

Using the moderate saline water irrigation as an example, the change of salt in the soil profile during a 1 -year period after reaching the equilibrium conditions is presented in Fig. 4. After planting the crop, the soil was irrigated with $30-\mathrm{mm}$ fresh water. Together with three precipitations totaling of $72 \mathrm{~mm}$ (not shown in the graph), the amount of water input was higher than the plant water consumption. Consequently, there was a decrease in the average soil salinity before the first irrigation of saline water. After that, the soil salinity increased in response to the saline water irrigation. Afterwards, the soil salinity slowly rebounded to the level at the beginning of the crop season.

Under the equilibrium conditions, the annual plant water uptake was $446 \mathrm{~mm}$ for the non-saline water irrigation. It was reduced to $432 \mathrm{~mm}$ for the moderate saline water irrigation, and to $390 \mathrm{~mm}$ for the high saline water irrigation. Consequently, the water leaching from the $1.0-\mathrm{m}$ soil profile increased from $15 \mathrm{~mm}$ for the non-saline water treatment, to $40 \mathrm{~mm}$, and to $62 \mathrm{~mm}$, respectively, for the moderate and high saline water treatments.

The distribution of salt along the $1.0-\mathrm{m}$ soil profile under the three water irrigation treatments at their respective equilibrium conditions are presented in Fig. 5. There were layers of high and low salinity levels in the profile due to different soil hydraulic properties among the five soil layers. Under the non-saline water irrigation, the $\mathrm{EC}_{\mathrm{e}}$ in the top $0.4-\mathrm{m}$ soil layer was less than $1.0 \mathrm{dS} \mathrm{m}^{-1}$. Below that, the $\mathrm{EC}_{\mathrm{e}}$ increased linearly to $3.4 \mathrm{dS} \mathrm{m}^{-1}$. Under the moderate saline water irrigation, there was an accumulation of salt at the top soil layer $(0-0.02 \mathrm{~m})$ with $\mathrm{EC}_{\mathrm{e}}$ of $14.7 \mathrm{dS} \mathrm{m}^{-1}$. The $\mathrm{EC}_{\mathrm{e}}$ then decreased and kept at a level of around $10 \mathrm{dS} \mathrm{m}^{-1}$. Below the 0.6$\mathrm{m}$ soil layer, the soil salinity increased with depth and reached $14.4 \mathrm{dS} \mathrm{m}^{-1}$ at the bottom of the $1.0-\mathrm{m}$ soil profile. The salt distribution under the high saline water irrigation water followed a similar trend to the moderate saline water irrigation, but showed a much higher accumulation on the top layers. Maas and Grattan (1999) indicated that the cotton salinity stress starts at $\mathrm{EC}_{\mathrm{e}}$ of $7.7 \mathrm{dS} \mathrm{m}^{-1}$ and the yield is reduced by $50 \%$ when it exceeds $17 \mathrm{dS} \mathrm{m}^{-1}$. Based on these standards, the soil salinization problem was minor for cotton production under the non-saline water deficit irrigation practice,
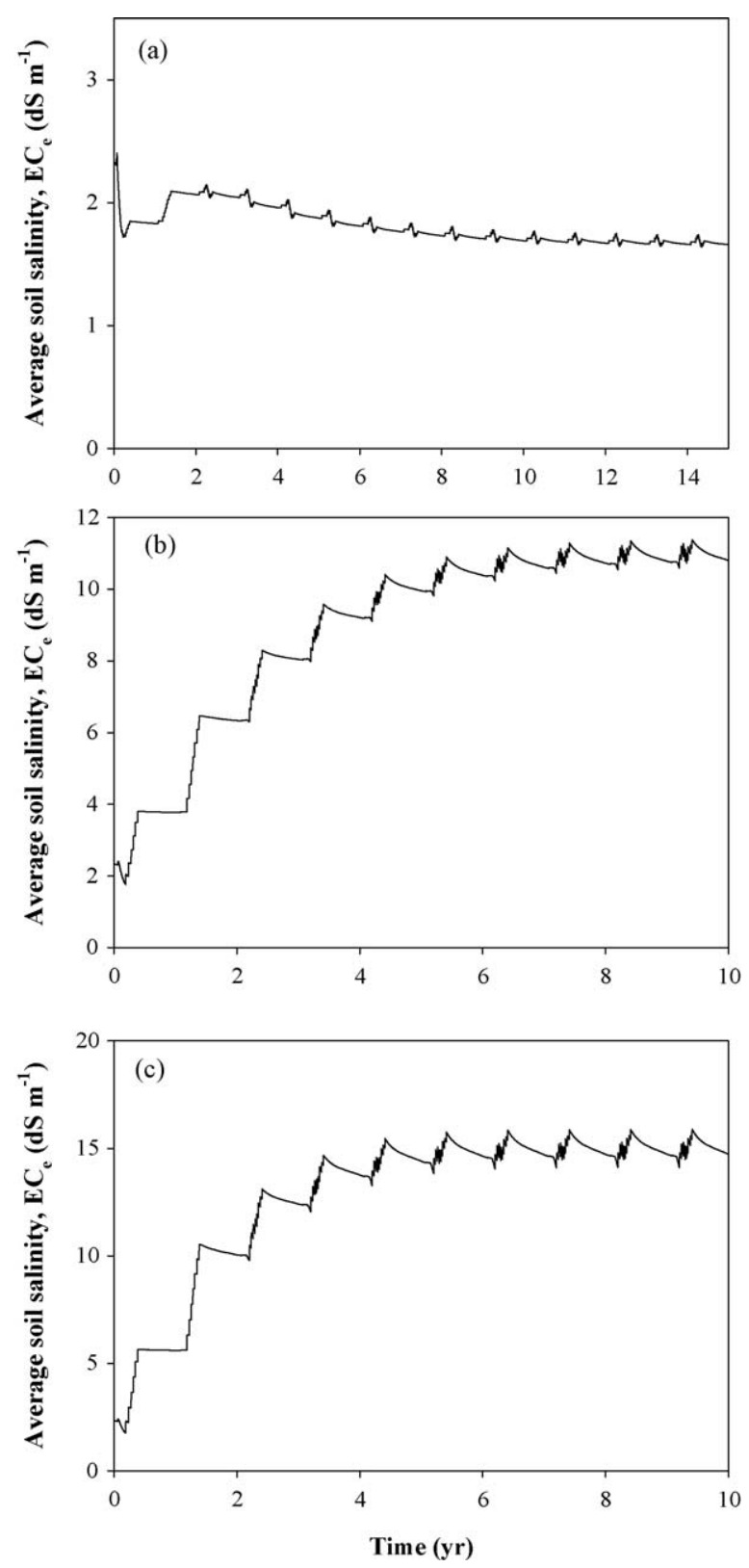

Fig. 3. Temporal change of the average soil-water salinity $\left(E C_{s w}\right)$ in the $1.0-\mathrm{m}$ soil profile under (a) non-saline water, (b) moderate saline water, and (c) high saline water irrigation.

since the salinity throughout the soil profile did not exceed the salinity stress threshold for cotton. But there were serious soil salinization problems for the saline water irrigation practices. Under the moderate saline water irrigation, the soil salinity in the profile was all above the salinity stress threshold. Under the high saline water, the issue became more serious. The salinity level of the top soil layers and bottom layers even exceeded the $50 \%$ yield threshold.

\subsection{Evaluating the salt distribution under different irrigation scenarios}

The changes of the average $\mathrm{EC}_{\mathrm{e}}$ in the 1.0 -m soil profile under the four different simulation scenarios specified in the previous section at the equilibrium conditions are presented in Fig. 6. As irrigation water increased from $353 \mathrm{~mm}$ (default) to $473 \mathrm{~mm}$ (scenario 1) and to $530 \mathrm{~mm}$ (scenario 2) during the crop season, more salts were leached out of the soil profile. The annual average $\mathrm{EC}_{\mathrm{e}}$ decreased 


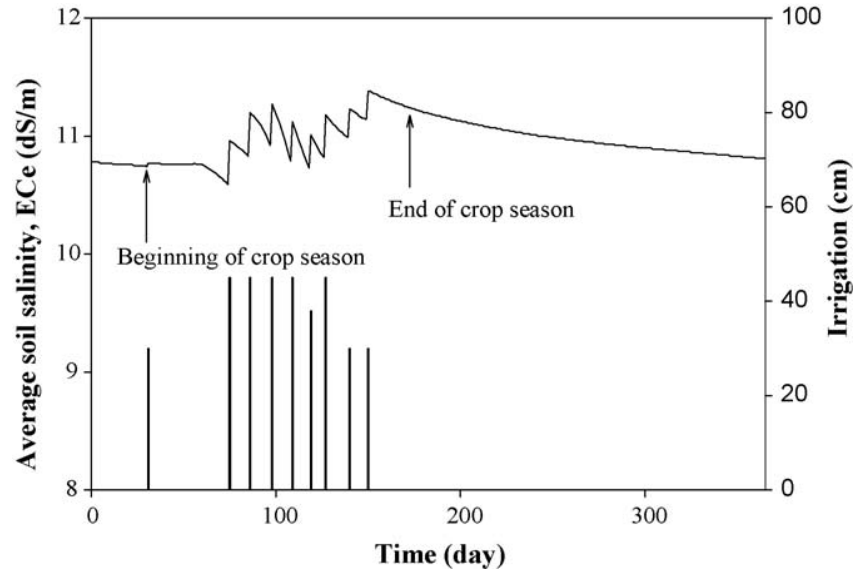

Fig. 4. Temporal change of the average soil salinity ( $\mathrm{EC}_{\mathrm{e}}$, left $Y$-axis) in the $1.0-\mathrm{m}$ soil profile in response to the irrigation (right $Y$-axis) in a 1-year period after reaching the equilibrium conditions. The salinity of irrigation water is $3.6 \mathrm{dS} \mathrm{m}^{-1}$, except for the first irrigation which is $0.3 \mathrm{dS} \mathrm{m}^{-1}$.

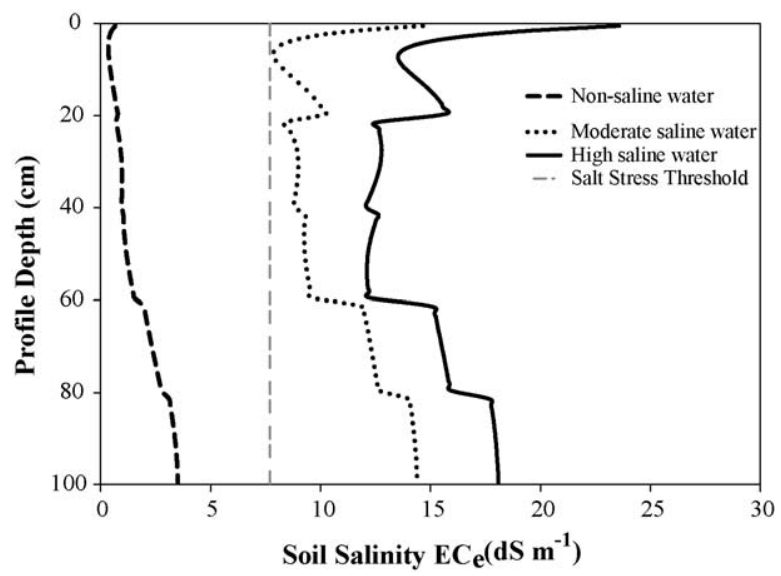

Fig. 5. Profile distribution of soil salinity $\left(E C_{e}\right)$ in the $1.0-\mathrm{m}$ soil profile for the three water irrigation treatments after reaching their equilibrium conditions.

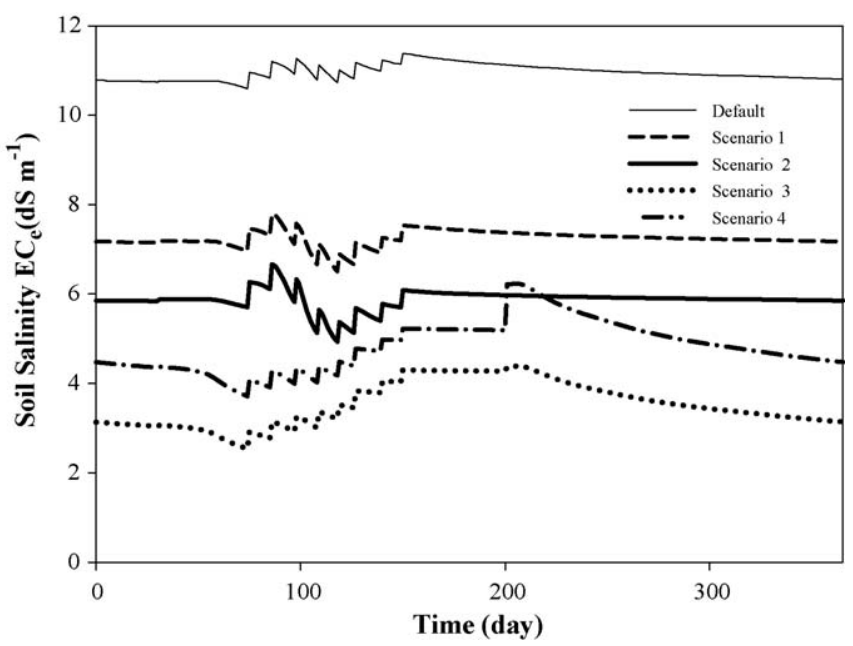

Fig. 6. Temporal change of the average soil salinity $\left(E_{e}\right)$ in the $1.0-m$ soil profile at the equilibrium conditions of selected simulation scenarios based on the irrigation schemes described in Table 4.

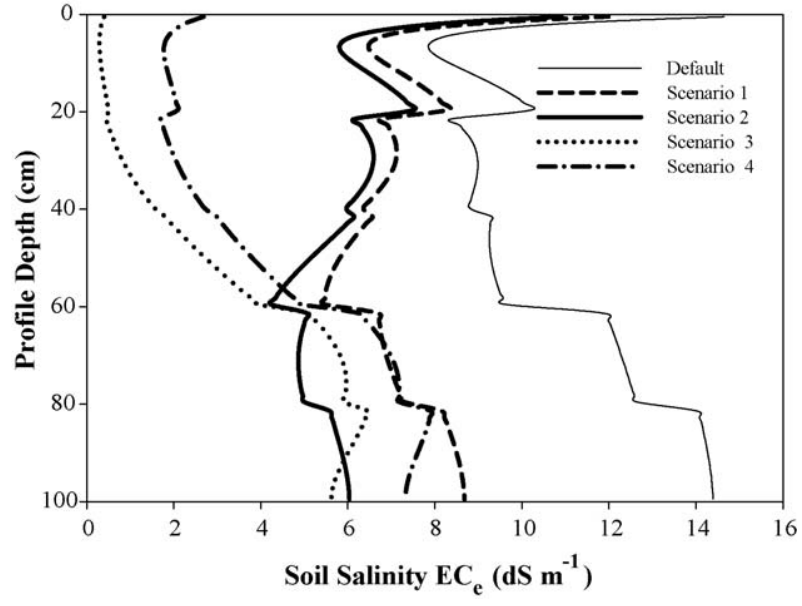

Fig. 7. Profile distribution of soil salinity $\left(\mathrm{EC}_{\mathrm{e}}\right)$ along the $1.0-\mathrm{m}$ soil profile at the equilibrium conditions of selected simulation scenarios based on the irrigation schemes described in Table 4.

from $10.96 \mathrm{dS} \mathrm{m}^{-1}$, to $7.23 \mathrm{dS} \mathrm{m}^{-1}$, and to $5.87 \mathrm{dS} \mathrm{m}^{-1}$, respectively. When the additional $120 \mathrm{~mm}$ water was applied as one flooding irrigation (scenario 3 and 4) after crop harvest, rather than applied during the growing season (scenario 1 ), salt leaching increased significantly. The annual average $\mathrm{EC}_{\mathrm{e}}$ was reduced to $4.82 \mathrm{dS} \mathrm{m}^{-1}$ when using saline water as flooding irrigation (scenario 3 ) and to $3.53 \mathrm{dS} \mathrm{m}^{-1}$ when using non-saline water as flooding irrigation (scenario 4). Under these two simulation scenarios, the average $\mathrm{EC}_{\mathrm{e}}$ in earlier crop development stage was less than $4.5 \mathrm{dS} \mathrm{m}^{-1}$. Crops usually are most sensitive to salt during the emergence and early growth stages. Therefore, the irrigation practice of a big flooding irrigation after crop harvest is beneficial to germination and seedling development.

The distribution of salt along the $1.0-\mathrm{m}$ soil profile under these simulated management scenarios at the equilibrium conditions are presented in Fig. 7. As expected, soil salinity decreased with increased irrigation. The average salinity in the $1.0-\mathrm{m}$ soil profile $\left(E_{e}\right)$ under flooding irrigation with saline (scenario 3) and nonsaline (scenario 4 ) waters was $33 \%$ and $51 \%$, respectively, lower than in 473-mm irrigation during the crop season (scenario 1). Salinity levels were reduced remarkably from the top root zone by flooding after crop harvest. The results demonstrate that the irrigation management of flooding after the harvest has advantages in term of preventing salt accumulation, saving water and benefiting the germination and seedling development. Using the model, more simulations can be conducted to identify the best management practices for saline water irrigation under specific soil, plant and climate conditions.

\section{Conclusions}

Water resources conservation is one of the key issues for sustainable agricultural development in arid and semi-arid regions where agricultural productivity is significantly affected by soil salinity. Computer simulation models are a valuable tool to evaluate the effects of different management strategies on salt distribution in the soil profile. Our study demonstrates that the ENVIRO-GRO model can be successfully used in simulating the consequences of irrigation management practices under saline conditions. But a 1D model may not be adequate to represent the 3D water and salinity movement and water uptake in soil such as under drip irrigation.

Both field experiment and model simulation indicated that under deficit irrigation, salinity can soon built up in the soil to levels that exceed the crop (cotton) salt tolerance. Excessive soluble 
salts in irrigated soils can be leached out of the root zone through either increasing the amount of irrigation during the growing season or flooding the soil after harvest. Model simulation shows that flooding after harvest is more efficient in reducing soil salinity and increasing crop production.

\section{Acknowledgements}

We would like to thank for the support of National Basic Research Program of China (\#2009CB85100) and the support of National Natural Science Foundation of China (\#30960210).

\section{References}

Allen, R.G., Pereira, L.S., Raes, D., Smith, M., 1998. Crop evapotranspiration guidelines for computing crop water requirements. Paper No. 56, FAO, Rome, Italy.

Ayers, R.S., Westcot, D.W., 1985. Water quality for agriculture. FAO Irrigation and Drainage Paper 29, FAO, Rome, Italy.

Bajwa, M.S., Josan, A.S., Hira, G.S., Singh, N.T., 1986. Effect of sustained saline irrigation on soil salinity and crop yields. Irrig. Sci. 7, 27-35.

Beltran, J.M., 1999. Irrigation with saline water: benefits and environmental impact. Agric. Water Manage. 40, 183-194.

Corwin, D.L., Rhoades, D.J., Simunek, J., 2007. Leaching requirement for soil salinity control: steady-state versus transient models. Agric. Water Manage. 90, $165-180$.

Dudely, L.M., Ben-Gal, A., Shani, U., 2008. Influence of plant, soil, and water on the leaching fraction. Vadose Zone J. 7, 420-425.

Feng, G.L., Meiri, A., Letey, J., 2003a. Evaluation of a model for irrigation management under saline conditions. I. Effects on Plant Growth. Soil Sci. Soc. Am. J 67, 71-76.

Feng, G.L., Meiri, A., Letey, J., 2003b. Evaluation of a model for irrigation management under saline conditions. II. Salt distribution and rooting pattern effects. Soil Sci. Soc. Am. J. 67, 77-80.

Forkutsa, I., Sommer, R., Shirokova, Y.I., Lamers, J.P.A., Kienzler, K., Tischbein, B., Martius, C., Vlek, P.L.G., 2009a. Modeling irrigated cotton with shallow groundwater in the Aral Sea Basin of Uzbekistan. II. Soil salinity dynamics. Irrig. Sci. 27, 319-330.

Forkutsa, I., Sommer, R., Shirokova, Y.I., Lamers, J.P.A., Kienzler, K., Tischbein, B., Martius, C., Vlek, P.L.G., 2009b. Modeling irrigated cotton with shallow groundwater in the Aral Sea Basin of Uzbekistan. I. Water dynamics. Irrig. Sci. 27, 331-346.

Gelhar, L.W., Mantoflou, A., Welty, C., Reyfeldt, K.R., 1985. A review of field scale physical solute transport processes in saturated and unsaturated porous media. Rep EA-4190, Electro Power Res Ins, Palo Alto, California.

Hanson, J.D., Ahuja, L.R., Shaffer, M.D., Rojas, K.W., DeCoursey, D.G., Farahani, H., Johnson, K., 1998. RZWQM: simulating the effects of management on water quality and crop production. Agric. Syst. 57, 161-195.

Hollins, S.E., Ridd, P.V., Read, W.W., 2000. Measurement of the diffusion coefficient for salt in salt flat and mangrove soils. Wetl. Ecol Manage. 8, 257-262.

Hou, Z., Li, P., Gong, J., Wang, Y., 2007. Effect of different soil salinity levels and application rates of nitrogen on the growth of cotton under drip irrigation. Chin. J. Soil Sci. 38, 681-686 (in Chinese).
Hutson, J.L., Wagenet, R.J., 1992. LEACHM: Leaching Estimation and Chemistry Model: A Process based Model of Water and Solute Movement Transformations, Plant Uptake and Chemical Reactions in the Unsaturated Zone. Continuum, vol. 2. Water Resources Inst, Cornell University, Ithaca, NY, Version 3.

Khan, S., Xevi, E., Meyer, W.S., 2003. Salt, water, and groundwater management models to determine sustainable cropping patterns in shallow saline groundwater regions of Australia. J. Crop Prod. 7, 325-340.

Leonard, R.A., Knisel, W.G., Still, D.A., 1987. GLEAMS: groundwater loading effects of agricultural management systems. Trans. ASAE 30, 1403-1418.

Lyman, W.J., Reidy, P.J., Levy, B., 1992. Mobility and Degradation of Organic Contaminants in Subsurface Environments. Smoley CK Inc., Chelsea, Michigan, p. 217.

Maas, E.V., Grattan, S.R., 1999. Crop yield as affected by salinity. Agricultural Drainage, Agronomy Monograph no. 38, vol. 13-54, ASA, Madison, WI.

Malash, N.M., Flowers, T.J., Ragab, R., 2008. Effect of irrigation methods, management and salinity of irrigation water on tomato yield, soil moisture and salinity distribution. Irrig. Sci. 26, 313-323.

Mohammad, M.J., 2004. Squash yield, nutrient content and soil fertility parameters in response to methods of fertilizer application and rates of nitrogen fertigation. Nutr. Cycl. Agroecosyst. 68, 99-108.

Nash, J.E., Sutcliffe, J.V., 1970. River flow forecasting through conceptual models part I. A discussion of principles. J. Hydrol. 10, 282-290.

Oster, J.D., Wichelns, D., 2003. Economic and agronomic strategies to achieve sustainable irrigation. Irrig. Sci. 22, 107-120.

Pang, X.P., Letey, J., 1998. Development and evaluation of ENVIRO-GRO, an integrated water, salinity, and nitrogen model. Soil Sci. Soc. Am. J. 62, 1418-1427.

Plaut, Z., Carmi, A., Grava, A., 1996. Cotton root and shoot responses to subsurface drip irrigation and partial wetting of the upper soil profile. Irrig. Sci. 16, 107-113.

Ragab, R., Malash, N., Abdel Gawad, G., Arslan, A., Ghaibeh, A., 2005. A holistic generic integrated approach for irrigation, crop and field management. 1. The SALTMED model and its calibration using field data from Egypt and Syria. Agric. Water Manage. 78, 67-88.

Singh, R., Singh, J., 1996. Irrigation planning in cotton through simulation modeling Irrig. Sci. 17, 31-36.

Simunek, J., Suarez, D.L., Sejna, M., 1996. The UNSATCHEM software package for simulating one-dimensional variably saturated water flow, heat flow, carbon dioxide production and transport, and solute transport with major ion equilibrium and kinetic chemistry, Version 2. Res. Report No. 141. USDA-ARS, U.S Salinity Lab., Riverside, CA, 186 pp.

van Genuchten, M.T., 1987. A numerical model for water and solute movement in and below the root zone. Res Report No. 121, USDA-ARS US Salinity Laboratory, Riverside, California.

van Genuchten, M.T., 1980. A closed-form equation for predicting the hydraulic conductivity of unsaturated soils. Soil Sci. Soc. Am. J. 44, 892-898.

van Schilfgaarde, J., 1994. Irrigation-a blessing or a curse. Agric. Water Manage. 25, 203-219.

Wang, Y.G., Xiao, D.N., Li, Y., Li, X.Y., 2008. Soil salinity evolution and its relationship with dynamics of groundwater in the oasis of inland river basins: case study from the Fubei region of Xinjiang Province, China. Environ. Monit. Assess. 140, 291-302.

Willmott, C.J., 1981. On the validation of model. Phys. Geogr. 2, 184-194. 